\title{
Quality in higher education- Evidence from Pakistan
}

\author{
Talib Hussain
}

\begin{abstract}
Education has different meanings as per different approaches. The quality in education is a complex and multicultural process. This study was conducted to check the Quality in higher Education. Four higher institutions were taken as sample. Out of which two were from public sector. The theoretical frame work consisted of the dependent variable which was, "Quality in Higher Education", and the independent variables which were Management, Faculty, Infrastructure, Research Facilities and Evaluation Criteria. Overall results showed that majority (73\%) respondents were in view that there is quality in education in higher education institutions. The most important factor which helps to maintain quality in higher education is the evaluation criteria in examinations (responded 23\%). The lack of proper infrastructure is the main problem of education institutions (responded 35\%). The above results show that quality in higher education is an essential tool to boost up the education sector of any country.
\end{abstract}

Keywords: Education, Quality Education, Management, faculty, infrastructure, academic polices.

\section{INTRODUCTION}

Education has different meanings as per different approaches. Generally, different authors define education as the, "Delivery of knowledge from teachers to students", the important thing here is that it depends upon the purpose and objective of that education. In another words it can be say that education means to receive some mental enhancement in terms of thoughts and believes. Berg, (2012), defines education as the person who thinks himself as an educated person is liable to set goals and objective for himself and plan to achieve them as well. The meaning of quality is differing from person to person and situation to situation, depending on circumstances and perceptions. In case of tangible products it varies as compare to the perception about services. Quality in common means that the product or service does, what it intended to do (Glasser, 1990). The quality in education includes learners, environment, content, processes and outcomes that encompass the knowledge, skill and attitude. The definition of quality in context of education is a complex task especially in higher education. Higher education is a level of education which starts after twelve year of education. According to Lawton and Gordon (1993), higher education is a course of study which results in award of a degree, diploma or similar advance qualification, to attain for further education. In developing countries education is seen as the mean of life for whole nation.

Education is the process of facilitating learning. Knowledge, skills, values, beliefs, and habits of a group of people are transferred to other people, through storytelling, discussion, teaching, training, or research. Education frequently takes place under the guidance of educators, but learners may also educate themselves in a process called autodidactic learning. Any experience that has a formative effect on the way one thinks, feels, or acts may be considered educational.

Talib Hussain is a PhD scholar at Shanghai Jiotong University, China, talibhussain313@yahoo.com

\begin{tabular}{llll}
\hline JISR-MSSE & Volume 13 & Number 2 & July-Dec 2015 \\
\hline
\end{tabular} 
Education is commonly and formally divided into stages such as preschool, primary school, secondary school and then college, university or apprenticeship. The methodology of teaching is called pedagogy. A right to education has been recognized by some governments. At the global level, Article 13 of the United Nations' 1966 International Covenant on Economic, Social and Cultural Rights recognizes the right of everyone to an education. Although education is compulsory in most places up to a certain age, attendance at school often isn't, and a minority of parents chooses home-schooling, sometimes with the assistance of modern electronic educational technology (also called e-learning). Education can take place in formal or informal settings.

Formal education occurs in a structured environment whose explicit purpose is teaching students. Usually, formal education takes place in a school environment with classrooms of multiple students learning together with a trained, certified teacher of the subject. Most school systems are designed around a set of values or ideals that govern all educational choices in that system. Such choices include curriculum, physical classroom design, student-teacher interactions, and methods of assessment, class size, educational activities, and more.

Preschools provide education from ages approximately three to seven, depending on the country, when children enter primary education. These are also known as nursery schools and as kindergarten, except in the USA, where kindergarten is a term used for primary education. Kindergarten "provides a child-centered, preschool curriculum for three- to seven-year-old children that aim[s] at unfolding the child's physical, intellectual, and moral nature with balanced emphasis on each of them. Primary (or elementary) education consists of the first five to seven years of formal, structured education. In general, primary education consists of six to eight years of schooling starting at the age of five or six, although this varies between, and sometimes within, countries. Globally, around $89 \%$ of children aged six to twelve are enrolled in primary education and this proportion is rising. Under the Education for All programs driven by UNESCO, most countries have committed to achieving universal enrollment in primary education by 2015 , and in many countries, it is compulsory. The division between primary and secondary education is somewhat arbitrary, but it generally occurs at about eleven or twelve years of age. Some education systems have separate middle schools, with the transition to the final stage of secondary education taking place at around the age of fourteen. Schools that provide primary education are mostly referred to as primary schools or elementary schools. Primary schools are often subdivided into infant schools and junior school.

In India, for example, compulsory education spans over twelve years, with eight years of elementary education, five years of primary schooling and three years of upper primary schooling. Various states in the republic of India provide 12 years of compulsory school education based on a national curriculum framework designed by the National Council of Educational Research and Training.

In most contemporary educational systems of the world, secondary education comprises the formal education that occurs during adolescence. It is characterized by transition from the typically compulsory, comprehensive primary education for minors, to the optional, selective tertiary, "postsecondary", or "higher" education (e.g. university, vocational school) for adults. Depending on the system, schools for this period, or a part of it, may be called secondary or high schools, gymnasiums, lyceums, middle schools, colleges, or vocational schools. The exact meaning of any of these terms varies from one system to another. The exact boundary between primary and secondary education also varies from country to country and even within them, but is generally around the seventh to the tenth year of schooling. Secondary education

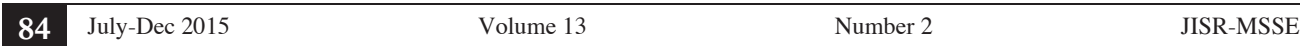


occurs mainly during the teenage years. In the United States, Canada and Australia, primary and secondary education together are sometimes referred to as K-12 education, and in New Zealand Year 1-13 is used. The purpose of secondary education can be to give common knowledge, to prepare for higher education, or to train directly in a profession.

Higher education, also called tertiary, third stage, or postsecondary education, is the non-compulsory educational level that follows the completion of a school such as a high school or secondary school. Tertiary education is normally taken to include undergraduate and postgraduate education, as well as vocational education and training. Colleges and universities mainly provide tertiary education. Collectively, these are sometimes known as tertiary institutions. Individuals who complete tertiary education generally receive certificates, diplomas, or academic degrees. Higher education typically involves work towards a degree-level or foundation degree qualification. In most developed countries a high proportion of the population (up to 50\%), now enter higher education at some time in their lives. Higher education is therefore very important to national economies, both as a significant industry in its own right, and as a source of trained and educated personnel for the rest of the economy.

University education includes teaching, research, and social services activities, and it includes both the undergraduate level (sometimes referred to as tertiary education) and the graduate (or postgraduate) level (sometimes referred to as graduate school). Universities are generally composed of several colleges. In the United States, universities can be private and independent like Yale University; public and state-governed like the Pennsylvania State System of Higher Education; or independent but state-funded like the University of Virginia. A number of career specific courses are now available to students through the Internet. One type of university education is a liberal arts education, which can be defined as a "college or university curriculum aimed at imparting broad general knowledge and developing general intellectual capacities, in contrast to a professional, vocational, or technical curriculum."Although what is known today as liberal arts education began in Europe, the term "liberal arts college" is more commonly associated with institutions in the United States (Redden, E. 2009).

Informal learning is one of three forms of learning defined by the Organisation for Economic Co-operation and Development (OECD). Informal learning occurs in a variety of places, such as at home, work, and through daily interactions and shared relationships among members of society. For many learners this includes language acquisition, cultural norms and manners. Informal learning for young people is an ongoing process that also occurs in a variety of places, such as out of school time, in youth programs at community centers and media labs.

Informal learning usually takes place outside educational establishments, does not follow a specified curriculum and may originate accidentally, sporadically, in association with certain occasions, from changing practical requirements. It is not necessarily planned to be pedagogically conscious, systematic and according to subjects, but rather unconsciously incidental, holistically problem-related, and related to situation management and fitness for life. It is experienced directly in its "natural" function of everyday life and is often spontaneous. The concept of 'education through recreation' was applied to childhood development in the 19th century. In the early 20 th century, the concept was broadened to include young adults but the emphasis was on physical activities. It was also an early proponent of lifelong learning, described education through recreation: "A master in the art of living draws no sharp distinction between his work and his play, his labour and his leisure, his mind and his body, his education and his recreation. He hardly knows which is which. He simply pursues his vision of excellence through whatever he is doing and leaves others to determine whether he is working or playing. To himself he always seems to be doing both. 
Education through recreation is the opportunity to learn in a seamless fashion through all of life's activities. The concept has been revived by the University of Western Ontario to teach anatomy to medical students.

The preferences of developing countries are changing with respect to time. The role of the universities in a developing country must be well to educate their people. Developing countries are rich in natural resources; the need is to explore them. This exploration of resources can only possible by giving quality education (Wickrama, 1996). Quality in higher education builds the nations. Globally we can see a war among the developed countries to build their youths by giving quality education. In Pakistan there are lots of institutions which educate the youth in different styles. The basic purpose of this research paper is to check the perception quality in education. Following were the research questions and objectives of this study.

- What is the perception of master's students regarding quality in education with respect to different measures?

- What is the most important factor which contributes in maintaining the quality in higher education?

- What is the worst factor which Universities do not take care to maintain the quality in higher education?

- Recommendations for higher education institutions to maintain Quality in education.

- Policies of Higher Education Commission Pakistan to rank universities in Pakistan.

\section{Higher Education}

Higher education, post-secondary education, or third level education is an optional final stage of formal learning that occurs after secondary education. Often delivered at universities, academies, colleges, seminaries, and institutes of technology, higher education is also available through certain college-level institutions, including vocational schools, trade schools, and other career colleges that award academic degrees or professional certifications. Tertiary education at non-degree level is sometimes referred to as further education or continuing education as distinct from higher education.

The right of access to higher education is mentioned in a number of international human rights instruments. The UN International Covenant on Economic, Social and Cultural Rights of 1966 declares, in Article 13, that "higher education shall be made equally accessible to all, on the basis of capacity, by every appropriate means, and in particular by the progressive introduction of free education". In Europe, Article 2 of the First Protocol to the European Convention on Human Rights, adopted in 1950, obliges all signatory parties to guarantee the right to education. In the days when few pupils progressed beyond primary education, the term "higher education" was often used to refer to secondary education, which can create some confusion.

Higher education is an educational level that follows a completion of a school providing a secondary education, such as a high school, secondary school, or gymnasium. Tertiary education is normally taken to include undergraduate and postgraduate education, as well as vocational education and training. Colleges, universities, and institutes of technology are the main institutions that provide tertiary education (sometimes known collectively as tertiary institutions). Examples of institutions that provide post-secondary education are vocational schools, community colleges, independent colleges (e.g. institutes of technology), and universities in the United States, the institutes of technical and further education in Australia, pre-university colleges in Quebec, and the IEKs in Greece. They are sometimes known collectively as tertiary institutions. Completion of a tertiary education program of study

86 July-Dec $2015 \quad$ Volume $13 \quad$ Number $2 \quad$ JISR-MSSE 
generally results in the awarding of certificates, diplomas, or academic degrees.

Higher education includes teaching, research, exacting applied work (e.g. in medical schools and dental schools), and social services activities of universities. Within the realm of teaching, it includes both the undergraduate level, and beyond that, graduate-level (or postgraduate level). The latter level of education is often referred to as graduate school, especially in North America.

Since World War II, developed and many developing countries have increased the participation of the age group who mostly studies higher education from the elite rate, of up to 15 per cent, to the mass rate of 16 to 50 per cent. In many developed countries, participation in higher education has continued to increase towards universal or, what Trow later called, open access, where over half of the relevant age group participate in higher education. Higher education is important to national economies, both as an industry, in its own right, and as a source of trained and educated personnel for the rest of the economy. College educated workers have commanded a measurable wage premium and are much less likely to become unemployed than less educated workers. However, the admission of so many students of only average ability to higher education inevitably requires a decline in academic standards, facilitated by grade inflation. Also, the supply of graduates in many fields of study is exceeding the demand for their skills, which aggravates graduate unemployment and underemployment (Trow, M. 2007).

Higher education in some countries, including the United States, Canada, the United Kingdom, and Ireland, specifically refers to post-secondary institutions that offer Associate's degrees, Bachelor's degrees, Master's degrees, Education Specialist (Ed.S.) degrees or Doctor of Philosophy (Ph.D.) degrees, or their equivalents, and also higher professional degrees in areas such as dentistry, law, medicine, optometry, pharmacology and veterinary medicine. Such institutions may also offer non-degree certificates, which indicate completion of a set of courses comprising a body of knowledge on a particular topic, but the granting of such certificates is not the primary purpose of the institutions. Tertiary education is not a term used in reference to post-secondary institutions in the United States or Canada.

In literature education is defined as "Any act or experience that affects the mind of human being". In practical sense it has a very vital meaning; it includes all those practices and skills which build a society and change it as well and when needed. The education although should not categorized but it is important to understand the different situations of education in different levels. In our society leaning takes in schools, colleges and universities, we think that the education means only to learn some methodologies and concepts. In practical it differs, it includes two types of learning; the first is the formal learning and second is informal learning. George says that, teachers in schools, colleges and universities may be taken as the formal education factors for education while the vocational centers, libraries and internet can take as informal education tools (George, 1971).

The line to draw which is higher education and which is higher secondary and secondary education is quiet difficult, the reason is that every country defines this category of education with respect to their own approach. Some people believe that the higher education includes where minimum associate degrees are awarded, while some other says that the situation where the attendance is voluntary is higher education. By explaining about higher education Avery Mann says that higher education in United States includes Colleges and Universities, Liberal Arts Colleges, Graduate Schools, Community Colleges, Trade Schools and Institute of Technology's etc. (Mann, 2011) 


\section{Meaning of Quality}

The oxford dictionary defines quality as, "The standard of something which is assumed how much is it good as compare to the others" in another definition it was mentioned about quality that, it is a part of personal character especially something good". The term quality is defined differently with respect to the nature of field and scope. The quality in business means it is the excellence to be free from errors and mistakes or defects. In business as there are quality control institutions which evaluate the organizations with respect to international standards and local markets requirements and rate the products. The quality in education has the same concept as there are some institutions which rate the quality in education. Through these ratings we can take the quality as a stander tool to check the performance of any institution (Phillips et al, 2010).

The quality in education is a complex process and multicultural. In a research published by UNICEF it is stated that, the definition of quality in education must be open and challengeable as it should compare globally. A researcher Glasser says that the system which changes the data generation process and creates a self-assessment skill is a quality in education (Glasser, 1990).

\section{Factors Measuring Quality in Higher Education}

After consulting different studies, following factors are supposed to be responsible to measure the quality in education.

\section{Management}

Management in context of quality in education is related to the human resource facilitators of any education institution. The quality in equation is mainly depends on the management of the institution. The focal point from where other resources can be utilized in a proper way is management. A great researcher in his research article, explained the role of management and leadership as, "The organizations are should be leaded with competent leadership". The absence of leadership creates problems in organization. The decisions of the organizations are much more depends on the management and leadership. Leadership and management exist everywhere; in business the investors always seek the role and the qualities of the management. In education the investors which are absolutely the students, always seek the management roles. By the arguments of above researcher it is cleared that the management has a vital impact to maintain quality in education (Mills, 2005).

\section{Faculty}

Faculty means the resource persons in an education institution, who teach and guide a student. The oxford dictionary define faculty as," The inherent power or capability to perform or act, the capabilities are the abilities of human mind which push and help to create a new thing". The faculty in education means that the learned professions who have certain skills to train and educate others. The faculty role to maintain quality is explained in OECD report as, there are some factors which are relates to teachers capabilities to improve the quality i.e., knowledge of the field, pedagogic skill, self-criticalness, commitment to the job or task and the management capabilities (OCED, 1994). 


\section{Infrastructure}

Infrastructure is also one of the sources for the organizations. The productivity of the organization depends on the condition of infrastructure. In the research paper conducted by Carron and Chau suggested that the resources like technology and student oriented facilities give more out come to the students. The resources which may be the class room environment and extra facilities help the students to perform well. Quality in education will be there where the students are satisfied from the institutions environment. The more the students feel relax the more they are competent and productive and at last this productivity can be connected to the quality in higher education institutions (Caron and Chau, 1996).

\section{Research}

Research word is derived from the words "re" and "search", which means to rethink and investigate in a new way. Researchers always precede the ideas bring innovation in every field of life. A person cannot do research without the consent of any education institution. The affiliation to the institution reflects the quality of the research work. It is fact that the quality of education has a vital relationship with output. The students are the products of the universities if they perform well and share their contribution to the nation, if so they studied from a qualified institution. Research comprises "creative work undertaken on a systematic basis in order to increase the stock of knowledge, including knowledge of humans, culture and society, and the use of this stock of knowledge to devise new applications. It is used to establish or confirm facts, reaffirm the results of previous work, solve new or existing problems, support theorems, or develop new theories. A research project may also be an expansion on past work in the field. To test the validity of instruments, procedures, or experiments, research may replicate elements of prior projects, or the project as a whole. The primary purposes of basic research (as opposed to applied research) are documentation, discovery, interpretation, or the research and development (R\&D) of methods and systems for the advancement of human knowledge. Approaches to research depend on epistemologies, which vary considerably both within and between humanities and sciences. There are several forms of research: scientific, humanities, artistic, economic, social, business, marketing, practitioner research, etc. These capabilities eventually give the result of productivity. The contents and the research process of the education institutions reflect the research methodology of that institution. The approach of the institutions to publish their research in national and international journals is a way to check the quality of that institution in education (Geuna, 1999).

\section{Types of research}

Scientific research is a systematic way of gathering data and harnessing curiosity. This research provides scientific information and theories for the explanation of the nature and the properties of the world. It makes practical applications possible. Scientific research is funded by public authorities, by charitable organizations and by private groups, including many companies. Scientific research can be subdivided into different classifications according to their academic and application disciplines. Scientific research is a widely used criterion for judging the standing of an academic institution, such as business schools, but some argue that such is an inaccurate assessment of the institution, because the quality of research does not tell about the quality of teaching (these do not necessarily correlate totally).

Research in the humanities involves different methods such as for example hermeneutics and semiotics, and a different, more relativist epistemology. Humanities scholars usually do not search for the ultimate correct answer to a question, but instead explore the issues and details 
that surround it. Context is always important, and context can be social, historical, political, cultural or ethnic. An example of research in the humanities is historical research, which is embodied in historical method. Historians use primary sources and other evidence to systematically investigate a topic, and then to write histories in the form of accounts of the past.

Artistic research, also seen as 'practice-based research', can take form when creative works are considered both the research and the object of research itself. It is the debatable body of thought which offers an alternative to purely scientific methods in research in its search for knowledge and truth.

\section{Evaluation Criteria}

Education is a sustainable process and it should be evaluated properly. The institutions policies towards students grading plans have an impact to the capabilities of students. Those students who are evaluated very strict and well, are more potential as compare to the others. In a research paper by Barnes et al suggested that, the evaluation is a power to improving the quality in education. He said that there are different tools through which students can be evaluated i.e., annual exams, teaching strategies and task oriented targets etc (Barnes et al, 2000).

\section{Quality Content}

Quality content refers to the intended and taught curriculum of institutions. National goals for education, and outcome statements that translate those goals into measurable objectives should provide the starting point for the development and implementation of curriculum (UNICEF, 2000).

\section{METHODOLOGY OF STUDY}

\section{Population and Sample of the research}

The population of this research was Pakistan. The sampling frame was the HEC recognized universities and degree awarding institutions in Pakistan. The sample was based on non-probability convenience sampling. The sample institutions were four, out of which two were from public sector i.e., Universities were University of Karachi and Federal Urdu University and two were from private sector i.e., SZABIST, and Muhammad Ali Jinnah University.

\section{Content Validity}

The concept, "Quality in Higher Education-Empirical evidence from Pakistan”, was reviewed through experts and $\mathrm{PhD}$ approved supervisors and underwent the necessary changes. After approval of concept the constructs for this study were developed i.e., management, faculty, infrastructure, research and evaluation criteria. The five characteristics for each of the construct were developed and also reviewed by the experts.

\section{Theoretical Frame work}

The theoretical frame work for this research was developed keeping in view the relationship of variables with each other. The variables in this study were, Quality in Higher Education, Management, Faculty, Infrastructure, Research and Evaluation Criteria. The dependent variable was the Quality in Higher Education and the independent variables were Management, Faculty, Infrastructure, Research and Evaluation Criteria. 


\section{Schematic Diagram of Variables}

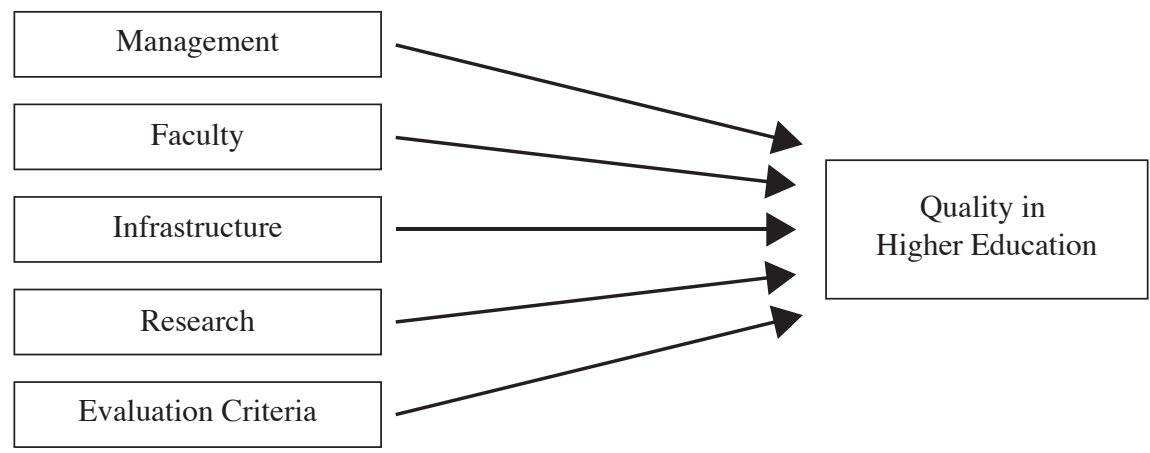

Figure-1 Schematic Diagram of Variables

The figure No.1 shows the relationships of the variables which are discussed below.

There is relationship between the dependent variable, Quality in Higher Education and independent variables, Management, Faculty, Infrastructure, Research and Evaluation Criteria.

\section{METHODOLOGY OF RESEARCH}

To collect the data a questionnaire was used which was designed in Likert five point scale. The questionnaire was administrated by the researcher personally. The places to approach the respondents were the sample institutions. Frequent visits were done to collect the data. To check the validity of questionnaire a pilot test of the questionnaires was conducted through 09 respondents. The result in table No. 1 shows that the validity of the questionnaire is valid as it is above the required reliability i.e., 0.7.To analysis the data SPSS and Excel were used. Table 2 suggests that the reliability of the research is satisfactory; eventually it can conclude that the research is valid overall. The content validity was also done by researcher by showing the contents of study e.g., theoretical frame work and questionnaire attributes to different $\mathrm{PhD}$ experts.

\section{Analysis and Discussions}

Graph No. 1 shows that overall result shows that majority $(73 \%)$ respondents are in view that there is quality in education in higher education institutions.

Table No 3 shows that majority of the respondents (74.9\%) mentioned that the management of the higher education institutions contributes well to maintain the quality in education. Table No. 4 shows that majority of the respondents $(83.5 \%$ responded) are in view that the faculty contributes well to main the quality in education in higher education institutions in Karachi. Table No. 5 shows that the infrastructure of the higher education institution is somehow enough to facilitate the students (Responded 53\% only). Table No. 6 shows that the majority of the respondents are in view that the higher education institutions are maintaining research habits in their students (Responded 73\%). Table No. 7 shows that there is a good evaluation criterion to judge the students in higher education institutions in Karachi (responded 78\%). 


\section{Most Important Attribute to Maintain the Quality in Higher Education}

Table No. 8 shows that the most important attribute to maintain the quality in higher education is the evaluation criteria in education institutions (responded 23\%).Graph No. 2 indicates clearly that the most important attribute which is maintained by institutions to improve the quality in education is the evaluation criteria.

\section{Most Important Issue to Maintain the Quality in Higher Education}

Table No 9 shows that the infrastructure of the institutions is insufficient for student's needs (Responded 35\%). Eventually it can be say that the lack of infrastructure is the main issues of the institutions. Graph No 3 shows that the other attributes are as such not very bad for maintaining quality in education; the lack infrastructure is the most important issue in the education institutions.

\section{HYPOTHESIS TESTS}

\begin{tabular}{ccccccc}
\hline Variables & Management & Faculty & Infrastructure & Research & $\begin{array}{c}\text { Evaluation } \\
\text { Criteria }\end{array}$ & $\begin{array}{c}\text { Quality in } \\
\text { Education }\end{array}$ \\
\hline $\begin{array}{c}\text { Pearson } \\
\text { Correlation }\end{array}$ & $0.062^{* *}$ & $0.201^{* *}$ & $0.216^{* *}$ & $0.237^{* *}$ & $0.210^{* *}$ & 1 \\
$\mathrm{~N}$ & 110 & 110 & 110 & 110 & 110 & 110 \\
\hline
\end{tabular}

Table No. 10: Hypothesis Tests

Table No. 10 shows that each independent variable has a positive relationship with dependent variable perception of quality in Higher education. This means that our all null hypothesis are rejected and we accept the alternative hypothesis. This also tells us about the relationship of the dependent variable quality in Higher education and independent variables management, faculty, research Infrastructure and evaluation criteria.

\section{RECOMMENDATIONS}

As in results it can be seen that the respondent's mentioned regarding the management quires time line (25\% oppose responded) and the financial support for the students in higher education institutions (responded 27\%), it will be better for these higher education institutions, if the quires response system will be managed well. If the quires of the students will be solved very well than their will not be any problem for students to study and learn. The second thing regarding management is that the students need financial help for higher education. There are lot of students who are talented but; due to financial constraints they cannot show their abilities in education. These two roles of the management will eventually help in maintaining the quality in higher education.

Although majority of the respondents are in view that the faculty of the higher education institutions are trying to maintain the quality measure in education, there are two factors which are responded very low $(21 \%)$. The first one is the lecture delivering methods i.e., respondents are in view that the faulty of the higher education institutions do not use the modern lecturing methods and delivering techniques. Secondly there should be some innovations in lectures delivering strategy, so that the knowledge may effectually be able to transfer to the students and eventually these both performances of faculty will help to maintain the quality in higher education. 
As the results regarding infrastructure of the institutions of higher education shows that there are as such no enough play grounds in the universities (responded 25.5\%). This facility is needed to be provided to students, so that they can play and be healthy in physical fitness. The physical fitness also helps to keep a good performance in education, so the institutions are supposed to facilitate in this regard. The research habits in education institutions help the students to groom their skills and abilities. As the research result shows that the higher education institutions are although offering the practical and research oriented courses but $26 \%$ of the respondents say that the institutions do not help them to publish their research in local and international journals. These institutions are needed to facilitate the students regarding the publication of the student's research. If institutions will help the students to publish their research at international level it automatically will bring quality in higher education.

The evaluation criteria help the institutions to maintain the quality in education. As the results shows positive responses regarding the evaluation criteria, but there are some poor contributions of the institutions which are needed to be better. The respondent's shown that the exams are not handled in time, which indirectly affects the students' abilities and reading habits (responded 22\%). The second most important thing which comes out regarding the evaluation criteria is that, the exams are not as such practical. The higher education institutions in Karachi are needed to change their exam pattern policies as well, for the betterment of the quality of education.

Although the respondents show positive response regarding the quality in higher education, there are some issues which need to be worked on in the institutions. The first thing is that the institutions are needed to maintain a very strict anti-plagiarism policy, secondly the access of the students to research journal and publication.

The education policies in Pakistan should be according to the student's perceptions and their needs, the results shows that there may be many solutions to keep up the quality in education if the standards will be set through students perceptions.

\section{CONCLUSION}

The research was all about quality in higher education. The results shows that the higher education institutions which are recognize by HEC are giving quality education. However there are some areas which should be kept in mind to maintain the quality in education. Among these, the most important is the infrastructure of the institutions (responded 35\%), as students are not satisfied from the physical facilities provided by the institutions. The second most important thing is the research habits and practices in these institutions, as $19 \%$ students say that the research journals are beyond their access. If the higher education institutions formulate their academic policies keeping in view of these results than there will be a better approach to maintain the quality in higher education. 


\section{REFERENCES}

Barnes, M. Clarke, D. and Stephens, M. (2000). Assessment the engine of systemic curricular reform: Journal of Curriculum Studies, 623-650.

Berg, D. (2012). Definition of Education, teach-Kids-Attitudes: http://www.teach-kids-attitude1st.com/definition-of-education.html.

Caron, G. and Chau, F. (1996). The quality of primary school in different context. Paris: UNESCO.

Creswell, J. W. (2008). Educational Research: Planning, conducting, and evaluating quantitative and qualitative research (3rd ed.). Upper Saddle River: Pearson.

George, F. Kneller, G. (2010). Introduction to the Philosophy of Education, New York: John Wiley and Sons, 1971. 20-21.

Geuna, A. (1999). The Economics of Knowledge Production: Funding and the Structure of University Research. Cheltenham, UK; Edward Elgar.

Glasser, W. (1990). The quality school: Managing School without coercion. Newyork, NY, Perennial Library.

Lawton, D. and P, Gordon. (1993). Dictionary of education, Great Britian for Hodder and Stoughton, London. U.K. P98.

Mann, A. (2011). what is Higher Education, http://www.americanprofile.com/articles/ what-is-higher-education/.

Mills, Q. (2005). The importance of Leadership, vol 1, www.mindedgepress.com/PDFs/htlhtl.pdf

OEC, D. (1994). Human Resource Development Canada: Literacy skills for knowledge, Canada.

Parkinson, D., Phillips, D. and Francis, B. (2010). Oxford advance learners Dictionary, NewYork.

Redden, Elizabeth (2009). "A Global Liberal Arts Alliance". Inside Higher Ed. Retrieved 2015-01-08.

Saunders, M. Lewise, P. and Thornhill, A. (2007). Research Methods for Business Students, pearson education limited, England.

Shuttleworth, Martyn (2008). "Definition of Research". Explorable. Explorable.com. Retrieved 14 August 2011.

Trow, M. (2007). Reflections on the transition from elite to mass to universal access: forms and phases of higher education in modern societies since WWII, Springer International Handbooks of Education volume 18, 2007, 243-280

Wickrama, B. (1996). Higher Education in Ceylon. UNESCO Bulletin, Vol. VIII No.1, UNESCO Asian Regional Office, Bangkok. P. 34. 
ANNEXURE

Table No: 1 Pilot test of Questionnaire

\begin{tabular}{|c|c|}
\hline \multicolumn{2}{|c|}{ Reliability Statistics } \\
\hline Cornbrash's Alpha & N of Items \\
\hline 0.947 & 41 \\
\hline
\end{tabular}

Table No 2 Reliability Statistics

\begin{tabular}{|c|c|}
\hline Alpha & No. of Items \\
\hline 0.785 & 6 \\
\hline
\end{tabular}

Graph No. 1 Graphical Representation of Overall Result

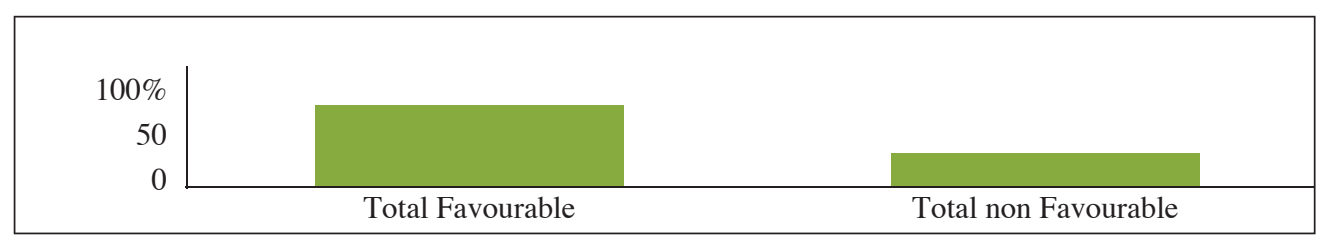

Table No. 3: Managements Contribution To maintain the Quality in Higher Education

\begin{tabular}{|c|c|c|c|c|c|}
\hline Statement & $\begin{array}{l}\text { Strongly } \\
\text { Agree }\end{array}$ & Agree & Disagree & $\begin{array}{l}\text { Strongly } \\
\text { Disagree }\end{array}$ & Total \\
\hline Management response students quires in time & 12 & 41 & 20 & 6 & 79 \\
\hline $\begin{array}{l}\text { Management adopts HEC policies and guidelines } \\
\text { in university for betterment of quality education }\end{array}$ & 23 & 52 & 10 & 6 & 91 \\
\hline Management finance faculty for higher studies & 7 & 32 & 23 & 5 & 67 \\
\hline $\begin{array}{l}\text { Management helps in maintaining and keeping } \\
\text { academic standers of university }\end{array}$ & 34 & 53 & 6 & 6 & 99 \\
\hline $\begin{array}{l}\text { Management provides help in resolving issues } \\
\text { of employs and students }\end{array}$ & 13 & 41 & 11 & 10 & 75 \\
\hline Total & 89 & 219 & 70 & 33 & 411 \\
\hline Percentage & $22 \%$ & $53 \%$ & $17 \%$ & $8 \%$ & 100 \\
\hline
\end{tabular}


Table No. 4: Faculty Contribution To maintain the Quality in Higher Education

\begin{tabular}{|l|l|l|l|l|l|}
\hline ST & SA & A & DA & SDA & Total \\
\hline The instructors use different teaching methods. & 22 & 52 & 10 & 6 & 90 \\
\hline The instructors encourage class participation of students & 34 & 53 & 6 & 6 & 99 \\
\hline The instructors deliver lectures effectively & 22 & 55 & 11 & 5 & 93 \\
\hline The instructors give course related assignments & 30 & 52 & 7 & 6 & 95 \\
\hline The instructors are available for consultations after class. & 29 & 36 & 12 & 7 & 84 \\
\hline Total & 137 & 248 & 46 & 30 & 461 \\
\hline Percentage & 29.7 & 53.8 & 9.978 & 6.5076 & 100 \\
\hline & TF & 83.5 & TUF & 16.4856 & \\
\hline
\end{tabular}

Table No. 5: Infrastructure Contribution To maintain the Quality in Higher Education

\begin{tabular}{|l|l|l|l|l|l|}
\hline Statement & Sa & A & DA & SDA & Total \\
\hline Students can avail the university library for research & 29 & 46 & 10 & 9 & 94 \\
\hline University is equipped with latest research facilities & 12 & 33 & 20 & 18 & 83 \\
\hline Washrooms & 21 & 42 & 19 & 12 & 94 \\
\hline Playgrounds & 9 & 19 & 36 & 29 & 93 \\
\hline Class rooms are well equipped and spacious & 10 & 34 & 21 & 14 & 79 \\
\hline Proper safety and security is available at university & 14 & 29 & 22 & 15 & 80 \\
\hline Total & 95 & 203 & 128 & 97 & 523 \\
\hline Percentage & 18 & 39 & 24 & 19 & 100 \\
\hline
\end{tabular}

Table No. 6: Research Contribution To maintain the Quality in Higher Education

\begin{tabular}{|l|l|l|l|l|l|}
\hline Statements & SA & A & DA & SDA & Total \\
\hline $\begin{array}{l}\text { The courses included research oriented projects } \\
\text { and assignments. }\end{array}$ & 17 & 59 & 11 & 6 & 93 \\
\hline $\begin{array}{l}\text { University offers for students to access research } \\
\text { journals and publications }\end{array}$ & 15 & 49 & 16 & 9 & 89 \\
\hline While doing research, anti-pilgrim policy is & 18 & 43 & 7 & 10 & 78 \\
\hline $\begin{array}{l}\text { University helps to publish research in local and } \\
\text { international journals }\end{array}$ & 7 & 42 & 12 & 17 & 78 \\
\hline University provide competent supervisors for research & 13 & 42 & 16 & 7 & 78 \\
\hline Total & 70 & 235 & 62 & 49 & 416 \\
\hline Percentage & 17 & 56 & 15 & 12 & 100 \\
\hline
\end{tabular}


Table No. 7: Evaluation Criteria Contribution To maintain the Quality in Education

\begin{tabular}{|l|l|l|l|l|l|}
\hline Statements & SA & A & DA & SDA & Total \\
\hline The themes of the exam are very conceptual & 16 & 51 & 5 & 7 & 79 \\
\hline The themes of the exam are very practical & 10 & 42 & 13 & 10 & 75 \\
\hline Quizzes and exams are taken in time & 16 & 47 & 18 & 7 & 88 \\
\hline The exams conducted by university are fair and unbiased & 34 & 40 & 8 & 8 & 90 \\
\hline $\begin{array}{l}\text { Students are evaluated by the competent instructors } \\
\text { throughout the academic duration }\end{array}$ & 17 & 55 & 10 & 8 & 90 \\
\hline The grading plan is very strict. & 37 & 39 & 12 & 6 & 94 \\
\hline $\begin{array}{l}\text { Total } \\
\text { Percentage }\end{array}$ & $\begin{array}{l}130 \\
25\end{array}$ & $\begin{array}{l}534 \\
53\end{array}$ & $\begin{array}{l}66 \\
13\end{array}$ & $\begin{array}{l}46 \\
8.9\end{array}$ & $\begin{array}{l}516 \\
100\end{array}$ \\
\hline
\end{tabular}

Table No. 8 Most Important Attribute to Maintain the Quality in Education

\begin{tabular}{|l|c|c|c|c|}
\hline Independent Variable & Strongly Agree & Agree & Total & Percentage \\
\hline Management & 89 & 219 & 308 & 17.4 \\
\hline Faculty & 139 & 248 & 387 & 21.9 \\
\hline Infrastructure & 95 & 203 & 298 & 16.8 \\
\hline Research & 86 & 286 & 372 & 21.0 \\
\hline Evaluation Criteria & 130 & 274 & 404 & 22.8 \\
\hline Total & 539 & 1230 & 1769 & 100.0 \\
\hline
\end{tabular}

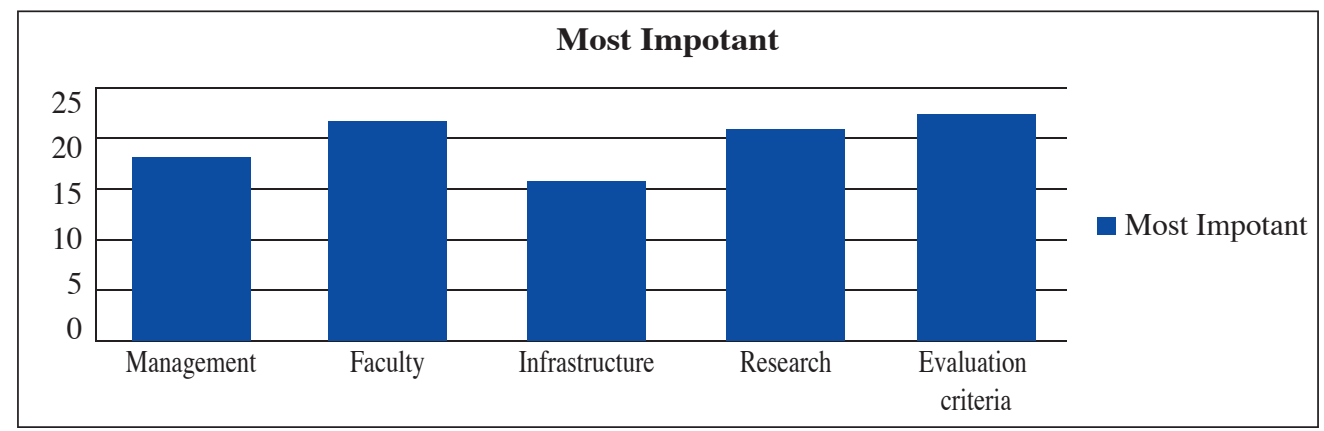

Graph No 2 Most Important Attribute to Maintain the Quality in Education

Table No 9 Most Important issue to Maintain the Quality in Education

\begin{tabular}{|l|l|l|l|l|}
\hline Independent Variable & DA & SDA & Total & \% \\
\hline Management & 70 & 33 & 103 & 16.119 \\
\hline Faculty & 46 & 30 & 76 & 11.894 \\
\hline Infrastructure & 128 & 97 & 225 & 35.211 \\
\hline Research & 67 & 56 & 123 & 19.249 \\
\hline Evaluation criteria & 66 & 46 & 112 & 17.527 \\
\hline Total & 377 & 262 & 639 & 100 \\
\hline JISR-MSSE & \multicolumn{2}{|c}{ July-Dec 2015 97 }
\end{tabular}


Graph No 3 Most Important Issues to Maintain the Quality in Education

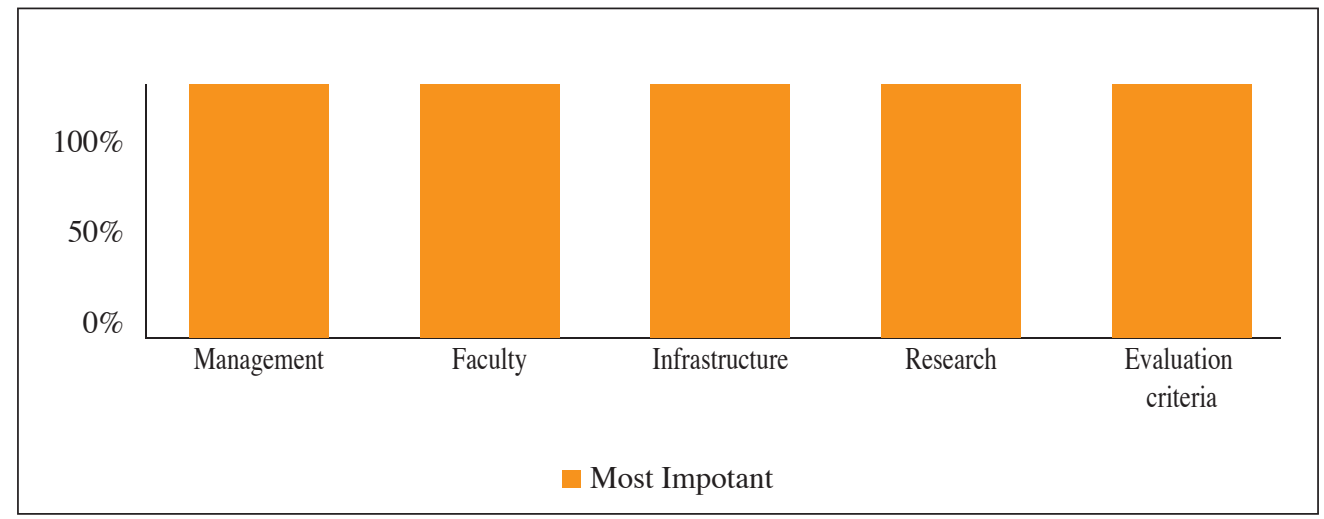

